\title{
AN ANALYSIS OF DIRECTIVE SPEECH ACTS BY SEARLE THEORY IN “SLEEPING BEAUTY” MOVIE SCRIPT
}

\author{
Fara Della \\ University of Bengkulu \\ Farradella@ymail.com \\ Barnabas Sembiring \\ University of Bengkulu \\ sembiring@yahoo.com
}

\begin{abstract}
This research aims to find out the types of Directive Speech Acts by the characters in "Sleeping Beauty" movie script based on the theory that proposed by Searle theory and analyze the types of directive speech acts that most frequently used in the movie script and the possible reason for it. The subject of the research was the script of the conversation between the characters. The type of this research is Descriptive Quantitative research. In this research, the researcher used documentation as the instrument. The object of this study is the "Sleeping Beauty" movie script by Casper Van Dien. The results of the research show that, first, the types of directive speech acts were Command, request, permission, prohibition and question. Second, the types of directive speech acts that most frequently used were command type. In terms of types, command is in the highest rank (51 utterances) and prohibition ( 2 utterances)) is in the lowest rank. In terms of reason, the command types (51 utterances) is the most frequently used, because it usually shows the strength of each character very clearly. And also the movie genre also influences the use of its directive speech acts itself.
\end{abstract}

Keywords: Pragmatics, Directive speech acts, Sleeping Beauty movie script

\begin{abstract}
Abstrak
Penelitian ini bertujuan untuk mengetahui jenis-jenis dari Directive Speech Acts yang dilakukan oleh para karakter dalam naskah film Sleeping Beauty berdasarkan teori dari Searle dan menganalisa tipe dari directive speech acts yang paling banyak digunakan dan alasan Untuk itu. Subjek penelitian ini adalah naskah percakapan para karakter. Jenis penelitian ini adalah penelitian kuanitatif deskriptif. Objek dari penelitian ini adalah naskah film Sleeping Beauty. Hasil penelitian menunjukkan bahwa, pertama,tipe-type dari directive speech acts berdasarkan teori dari Searle adalah command, request, question, permission dan prohibition. Kedua, tipe dari directive speech acts yang sering digunakan dalam film ini adalah tipe command karena ilm ini merupakan jenis film fantasy dan adventure. Dalam hal ini, tipe command berada di peringkat tertinngi ( 51 ucapan) dan prohibition( 2 ucapan) dengan $1.8 \%$ berada di peringkat terendah. Alasan yang ditemukan di naskah percakapan yang dilakukan di dalam film ini oleh para karakter adalah karena command biasanya menunjukkan kekuatan dari setiap karakter sangat jelasdan juga jenis film juga mempengaruhi dominant tipe yang sering di guanakan dari directive speech acts.
\end{abstract}




\section{INTRODUCTION}

Linguistics concerned with the nature of language and communication. It deals both with the study of particular languages, and the search for general properties common to all languages or large groups of languages. In making communication actually we need a partner or a hearer to understand and respond what we talking about. But, in some communication cases, speakers sometimes could not get their messages across to a different cultural background. Asa result it makes some misunderstanding between the hearers and speakers in a conversation, So, the message will not be easily well delivered to hearers as the way it is. One way to avoid the kind of misunderstanding is by learning about pragmatics which deals with meaning based on its social context.

Pragmatics is a branch of linguistics that concerns with meaning in use. Speech acts is the central point ofpragmatics itself. Speech act is the study of meaning and function of an utterance. It is used to clarify what the speaker does.

According to Yule ( 1996) there are 5 categories of speech acts, they are : Directive, commisive, declaration, and expressive One of the Important categories in speech acts is direction because it is used to get someone else to do something (paradigm cases: requesting, questioning, command, orders, suggesting, etc.).

Directive speech act is usually used in a movie. Movie is one of human product literature terms. It can express someone's thought, feeling, and meaning sense. In general, every movie has script and specific aim of the movie. In the movie, there are so many utterances which have different meaning from each other. Furthermore, we have to know what their conversational purposes are. Understanding the meaning of conversation is needed in order to avoid misunderstanding

Therefore, in this study researcher focuses on directive speech acts in the "sleeping beauty" movie script". There are three reasons why this study about directive speech act is still freshly conducted. First, directive speech act is a kind of speech act that is often used by speakers in daily conversation. Second reason is directive shows a strong relationship between speaker and hearer. The next reason is because directive speech acts are used to get or give attention from the speaker in communication.

There are several researchers who used theory of pragmatic in the term of speech acts especially in directive speech 
acts. The following previous studies used theory of conversational implicature. Firstly, a previous study from Oktoberia 2007entitled “ Directive Speech Acts used in Harry Potter-the DeathlyHallow and Bride Wars Movie Script. Secondly, the study from SuryoNugroho (2011) entitled "An analysis of illocutionary acts in "Sherlock Holmes " Movie. The last the study is from Sundari (2009) entitled "The Analysis of directive Illocutionary Acts

\section{METHOD}

This research used a descriptive quantitative method. The object of this research wasall utterances representing directive speech act found in sleeping beauty movie script. The descriptive quantitative method used in order to know the types of directive speech acts in sleeping beauty movie and count the frequently that most frequently used in this movie. In quantitative method, the researcher used some formula to get the data. The researcher count the percentage of directive speech acts in sleeping beauty movie script by using percentage formula as follow;

$$
P=\frac{F}{N} x 100 \%
$$

Where:

$\mathrm{P}=$ The percentage of utterances

$\mathrm{F}=$ Frequency of utterances in Archer's Utterance in the Movie Blood Diamond By Edward Zwick and Marshal Herskovits “

Therefore, based on the previous studies above, the researcher is interested in conducting a research with different theory which is Searle's Theory and the title of the research is "An Analysis of Directive Speech Acts by Searle theory in'Sleeping beauty " Movie script $\mathrm{N}=$ the total number of Directive Speech Acts

\section{RESULT AND DISCUSSION}

\section{Results}

The data of this research have been collected and analyzed by the researcher. The researcher found out the directive speech acts by the character use in this movie script. There were 111 utterances of this movie script that contain Directive speech acts. In those 111 utterances, the types of Directive speech acts were various and had different reference and meaning Based on the analyses above, below is the summary of directive speech act occurrences in the sleeping Beauty movie. 


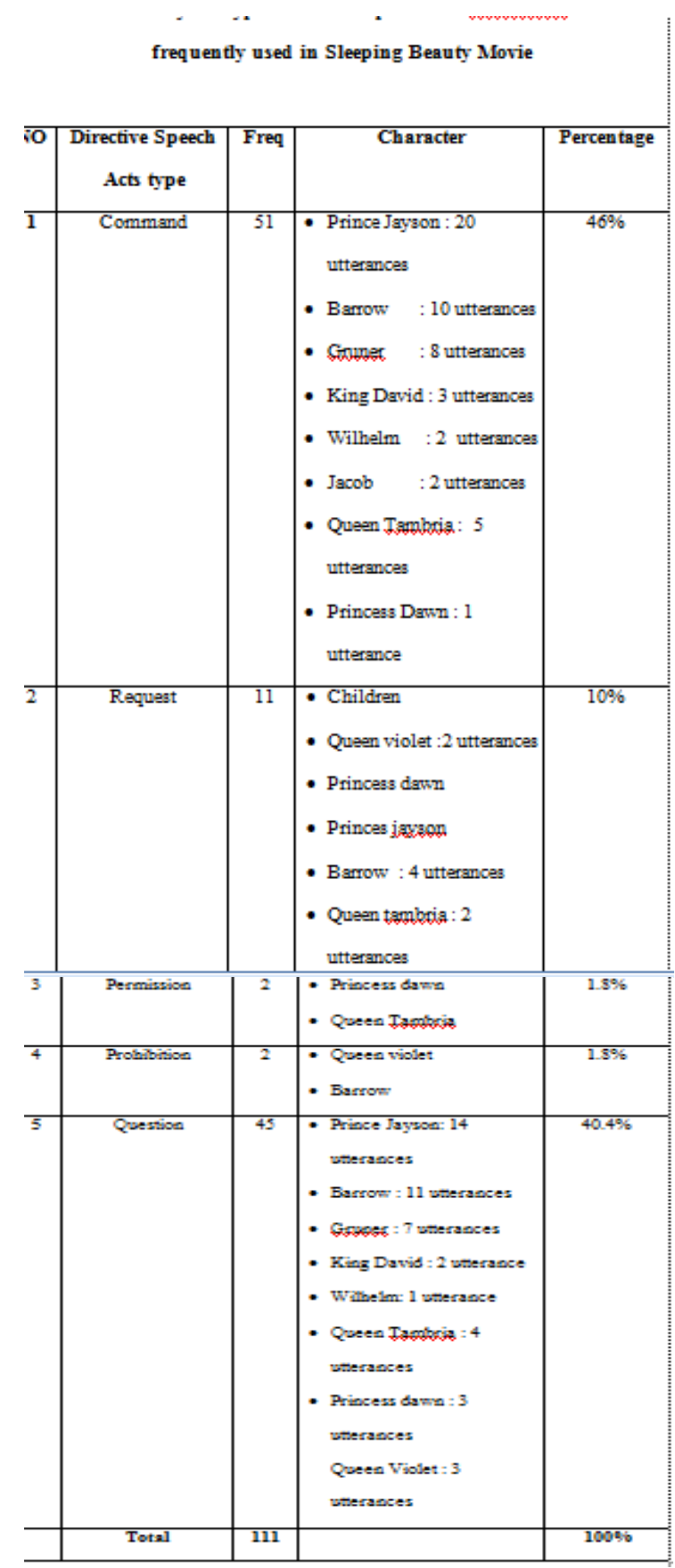

Total of directive speech acts occurrences is $=111$

Percentage is calculated using this formula:

$\mathbf{P}=\underline{\mathbf{F}} \times \mathbf{1 0 0 \%}$

\section{$\mathbf{N}$}

The table proves that directive speech acts used in Sleeping beauty were 111 utterances. They came in the form of command, question, permission, prohibition and request. Based on the table above, we can see that command consists of 51 utterances, 45 utterances from question, 11 utterances from request, 2 utterances from permission and 2 utterances from prohibition. The most frequently used by characterwas command with total 51 occurrences in each utterances with $46 \%$ and the least categories was prohibition with $1.8 \%$.

\section{Discussion}

Based on the objectives of this research, there are two parts of discussion concerning about Directive speech acts in the movie script, its types and reasons. The first discussion gives an in-depth explanation of the types of directive speech acts performed by each characters.

According to Searle, there are five types of directive speech acts; command, request, permission, prohibition and question. In sleeping beauty movie Script the most dominant directive speech acts was command types and the least dominant was prohibition types of directive. This result was supported by the result of Oktoberia's research (2007) . In his research, she found that the dominant type of directive speech acts used in sleeping beauty movie as fantasy and adventure movie was command type.

This result was the same as previous research, where the most dominant type of 
directive speech act used in the movie was command type. It was also shown in Nugroho's research (2011). In his research, it was found that directive represents the power and dominance of the speaker. Based on the table in this research, it was also shown that command type was more dominant than other types in directive speech acts.

However, it contrasts with Sundariresearch (2009), this research showed that asking $(38,72 \%)$ had the highest frequency because this movie is kind of drama movie. By looking at the phenomena above, the researcher concluded some facts for it. First, there were some types of directive speech acts that were used in sleeping beauty movie, such as command, request, permission, prohibition ad question types. Second, the dominant type that mostly appeared was command type. Third, the movie genre also influences the use of its directive speech acts.

\section{Suggestion}

For the student, it is expected that they learn more about directive speech act in order to understand easier the meaning of script in movie, not only in sleeping beauty but also in other movies. If people understand about the directive more, it will help them in communication with others.
For further research, the research hopes this research can be referable for further researchers to analysis directive speech act or other speech acts with the different object, such as comic, magazine, novel, etc. Finally, the researcher hopes that this study will give benefit for the English Education students who want to do the similar research.

\section{REFERENCES}

Austin, J. L. (1962). How to Do Things with Words. Great Britain: J. W. Arrowsmith Ltd Oxford : Clarendon Press

Alston, W. P. (2000). Illocutionary Acts and Sentence Meaning.Ithaca and London: Cornell University Press.

Chaer, Abdul.PengantarSemantikBahasa Indonesia. Jakarta: RinnekaCipta, 2009.

Levinson, S. C. (1983). Pragmatics

(Cambridge textbooks in linguistics). United Kingdom : Cambridge University Press Mukhtar, Prof.Dr.M.Pd.(2013).

\section{MetodePraktisPenelitianDeskriptifK ualitatif, Jakarta}

Nugroho, A. S. (2011). An Analysis of illocutionary acts in Sherlock Holmes movie. 
Oishi, E. (2006). Austin's speech act theory and the speech situation. EserciziFilosofici,1(2006), 1-14

Oktoberia, L., \&Hamzah, R. A. S. (2012). Directive Speech Acts Used In Harry Potter-The Deathly Hallow And Bride Wars Movie Script. E-Journal English Language and Literature, l(1).

Peccei, Jean Stilwell. Pragmatics. Great Britain: Routledge, 1999 Rahyono, F.X.KiatMenyusunSkripsidanStrategi Belajar di PerguruanTinggi. Jakarta: Penaku, 2010.

Sakakibara, E. command and Searle's Directive Illocutionary acts.

Searle, J. R. (1976). A classification of illocutionary acts. Language in society, 5(01), 1-23.

Searle, J. R. (1969). Speech acts: An essay in the philosophy of language (Vol. 626). Cambridge : University press.

Searle, J. R. (1985). Expression and meaning: Studies in the theory of speech acts. Cambridge University Press.

Sukamolson, S. (2010).Fundamentals of quantitative research.Language Institute, Chulalongkorn University. Sundari,H. (2009) .The Analysis of directive Illocutionary Acts in Archer's Utterance in the Movie Blood Diamond By Edward Zwick and Marshal Herskovits.

Yule, G. (1996). Pragmatics/George Yule. Oxford New York : University Press. https://ambarmizu2013.wordpress.co $\underline{m} /$ sosiolingusitik-tindak-tuturaustin-dan-searlel https://www.youtube.com/watch?v=n aX2WqMHJok

http://filmjunkieconfessions.blogspot .co.id/2014/08/a-review-of-sleepingbeauty-2014.html http://www.springfieldspringfield.co. uk/movie_script.php?movie=sleepin g-beauty-2014. 